\title{
Analysis the Risk of Online P2P Lending under the Background of Shar- ing Finance in China
}

\author{
Yawei Yang \\ School of Economics and Management, Beijing Jiaotong University, Beijing, China \\ 14120495@bjtu.edu.cn
}

\begin{abstract}
Keywords:sharing finance; online P2P lending; Internet Banking
Abstract:As a new financial format and a direct trading system between the two sides of the financial resources, it have special advantages in promoting the development of sharing economy and the realization of "Inclusive Finance". P2P network lending as a classic form of Internet banking, but also to accelerate the evolution of traditional finance to share the financial process, but also accompanied by the risk. In this paper, standing on the point of view of lender,risk of online P2P lending can be divided into two parts, one is the potential risk of lending platform, the other is default risk of borrower.Select 2015 March to 2016 February data samples, and combined with the typical case for nearly a year, in-depth analysis of the characteristics and influencing factors of nearly a year of platform, and for the P2P net loan industry to provide theoretical basis for the development of the road to maturity.
\end{abstract}

\section{Introduction}

As the core of modern economy, finance supports the development of economy, and the development of sharing economy can not be separated from the sharing finance. The current economy is in a downward phase, however, the money supply continued to increase, but there are still a lot of financial needs who can't finance the money, obviously there is a mismatch. To fundamentally solve this situation, it is necessary to integrate the resources and then share, so the sharing of financial exploration also appeared. The traditional financial system can not be fully consistent with the idea of sharing financial resources. Financial resources in China faces serious structural imbalances, P2P network lending industry by Internet technology, data technology of ship to sail. P2P network lending industry to meet the financial needs of small and micro enterprises, enhance the efficiency of the allocation of financial resources, guide private lending toward standardization and other aspects play an important role,but also has a very important significance in the realization of sharing of financial.

\section{Analysis of the cause of the problem platform}

The development of Internet technology and the mismatch between the supply and demand of funds for the rise of P2P lending provides the objective conditions and practical needs.Became the classic mode of sharing the financial moment, and serve the growth and sustainable development of a shared economic model.However, in recent years, with the explosive growth of the number of platforms, the platform on foot, collapse, fraud and other phenomena emerge in an endless stream, to the lender's financial security issues have brought a very bad impact.

By the end of February 2016, the occurrence rate of the platform problems is a steady growth in recent years, the new P2P platform up to 1804, the Problematic platform on a number of 931, the increment of the platform more than $50 \%$ of the new platform incremental.In recent months, the platform type increase a economic intervention types, indicating that the supervision of the P2P lending platform more stringent,From the ex post regulation extends to advance,to reduce the risk to the greatest extent.But from the point of view of statistical data for nearly a year,the economic investigation intervention platform less than 20. It also illustrates the effect of ex ante regulation is not significant.

Through the case of the platform on foot or collapse occurred nearly a year, it can be concluded that the characteristics of P2P platform on foot or collapse platform has the following aspects: 
One is pure fraud platform.Wanjun Wealth, for example, may 2015 on-line, the annual yield of the launch of the product were as high as $20 \%$, many investors are attracted by the high rate of return.However, when we inquire about the information of the enterprise in the enterprise information system,we found that the system does not have the registration information of the enterprise, the platform on foot in the month. So we can see that this kind of pure fraud platform mainly has information fraud, on-line time is short, commitment to high yield and other characteristics.

Second is to establish a pool of funds platform.TONGRONGYIDAI, for example, in order to encourage investors line recharge, commitment certain incentives, weak risk awareness of investors often tempted, putting money directly into the account designated by the platform, also save a sum fee to third-party funds depository payment.Funds were driven into their private accounts after the formation of a pool of funds, and then through the online lending funds, if there is a surplus of funds pool, they will be the rest of the funds to invest in high-risk products, and even misappropriation.In September 2015, the platform due to cash flow difficulties, and finally difficult to maintain operations, the platform on foot.

Although it is now more and more platform established third-party funds depository mechanism, but the number of issues with the platform or increasing, mainly because the network payment as a third party escrow funds exist a lot of defects,mainly is the third party online payment not track and review the subject matter of the platform. Therefore, the platform may publish false information about borrowers, for their own financing and capital have entered the pool of funds that they own built.

Third is the Pang's fraud platform.Some P2P platform using maturity mismatch funds to achieve the purpose of establishing a pool of funds that is a pang scheme. With more and more fraud, involving more and more investors, there are always investors can not get interest. When funding strand breaks, the bursting of the scam, the last period of investment become the biggest victims, the principal damage and even lose everything.By the end of 2015, the "E Rent Treasure" illegal fund-raising case, for example, by issuing false financial leasing project, and the use of high return rate to attract investors, adopted by the old new way to establish their own pool of funds, illegal absorb a lot of money, according to statistics, actual absorb funds amounted to more than 500 billion yuan. This is a typical Pang's scheme.

\section{Analysis of the borrower default risk}

P2P network lending industry to provide services belonging to the category of Inclusive Finance, the main target of its services are small businesses and some of the low income people can not get loans from banks.Also the credit system of our country is not very perfect, many platforms are based on the borrower to provide their own information or in the platform of transaction records to determine the credit situation, for the false information can not make a correct judgment, and P2P platform is unable to achieve the tracking each borrower loan funds use, which will undoubtedly increase the possibility of the borrower loans overdue, the large number of overdue loans and bad debts to investor funds security caused great threat.

\subsection{Analysis of the borrower's default risk Under the condition of complete information. Based}

on certain assumptions, using the game theory analysis method to analyze the P2P platform of the borrower's default risk.

First,in view of the current P2P network lending operation mode is complex and varied,and the previous paper also has a comprehensive analysis of the risk of the platform. So this article only consider to PPDAI as the representative of unsecured,as an intermediary platform.Under this model is entirely by lenders to bear the risk of financial security,and the lender and the borrower directly act on the loan;Second, assuming that the borrower and the lender are rational people, that is, the borrower will choose the maximum return between default and non default.And ruled out the sudden situation that leads to the borrowers lose the ability to repay the debt. Lenders only consider their own funds can repay the debt on time; Third, assuming that the borrower's income includes the 
interest of the borrower,the cost of the borrower includes interest costs;Fourth, assuming that the two sides of the game is under the conditions of complete information, there is no uncertainty.

The process of game analysis is as follows:

Model: assuming a normal operation of the P2P lending platform,lenders are considering whether a investment of a sum of money $\alpha$ to the platform.Lenders to lend a certain amount of time the capital obtained by the interest for the $\mathrm{R}$, the borrower to obtain the capital is to achieve the value of the capital $\mathrm{V}$, the cost is the loan interest $\mathrm{R}$, the borrower's default loss is $\beta$.Lenders have two strategies: investment and non investment; borrowers in accordance with the actions of the lender can have two strategies: default, that is not on time debt service, not default, that is, on time debt service.Game process can be expressed as:

Table 1 Game matrix

\begin{tabular}{|c|c|c|c|}
\hline \multirow{4}{*}{ borrower } & \multicolumn{3}{|c|}{ lender (investor) } \\
\cline { 2 - 4 } & & invest & Not to invest \\
\cline { 2 - 4 } & Default & $(\mathbf{V}+\boldsymbol{\alpha}+\mathbf{R}-\boldsymbol{\beta},-\boldsymbol{\alpha}-\mathbf{R})$ & $(\mathbf{0 , 0 )}$ \\
\cline { 2 - 4 } & No default & $\mathbf{( V - R , R )}$ & $\mathbf{( 0 , - R )}$ \\
\hline
\end{tabular}

Assuming the borrower default probability of $\mathrm{P}$,from the above payment matrix can be seen:

The expected return on the lender's choice of investment:

$$
\boldsymbol{\pi} \mathbf{1}=\mathbf{P} *(-\alpha-\mathbf{R})+(\mathbf{1}-\mathbf{P}) * \mathbf{R} \text {, that is }-\mathbf{P} \boldsymbol{\alpha}-\mathbf{2} \mathbf{R} \mathbf{P}+\mathbf{R}
$$

The expected return on the lender's chose not to invest:

$$
\boldsymbol{\pi} \mathbf{2}=\mathbf{P} * \mathbf{0}-\mathbf{( 1 - P )} * \mathbf{R} \text {, that is } \mathbf{R P}-\mathbf{R}
$$

Compare the value of both can be seen, when $\pi 1>\pi 2$, namely $\mathrm{P}<2 \mathrm{R} /(\alpha+3 \mathrm{R})$, the lender will choose to invest; When $\pi 1<\pi 2$, namely $\mathrm{P}>2 \mathrm{R} /(\alpha+3 \mathrm{R})$, the lender will choose not to invest. Therefore, whether the lenders choose to invest is related to the probability of a borrower's default behavior.

In the development process of P2P lending,Lenders are always the first to act,started to attract a lender is higher income.along with the increasing of the number of platforms, increasing many platforms because borrowers default caused a lot of bad debts and the collapse of the platform,quality of the borrower's repayment has been put to the test. Taking into account the safety of its own funds, lenders in the choice of investment when had to consider the lender's credit, that is, the higher the probability of default of the borrower, the less the investment platform.

Then we consider the more close to the actual situation, that lenders make decisions, the borrower in accordance with the lender's choice to make a default and non default choice.

According to the above game both sides of the payment matrix can be seen:In the case of lenders choose to invest, when $\mathrm{V}+\alpha+\mathrm{R}-\beta>\mathrm{V}-\mathrm{R}$, namely $\beta<\alpha+2 \mathrm{R}$, The borrower will choose default.Because at this point the cost of default is very small, compared to abide by the contract, the borrower's income is relatively large. On the contrary, if the cost of default is large enough, borrower compliance value is much higher than the income of default, so the borrower will choose to comply with the contractual.In the case of lenders choose not to invest in P2P lending, the borrower's income is 0 , therefore, the borrower can choose default, also can choose not to default.Obviously $(0,0)$ and $(0, R)$ is not realistic, a P2P platform without investors and borrowers can randomly selected for breach of contract and keeping promise, this platform can not act as information intermediary to match on both sides of the transaction lending, there is no survival significance.In summary, it can be concluded, in order to make $\mathrm{P} 2 \mathrm{P}$ lending platform can healthy development continues, the need to improve the borrower default costs, so as to reach Pareto optimality that lenders choose to invest, borrowers choose not to default.

3.2 Analysis of the borrower's default risk under incomplete information. Under the condition of information asymmetry, the main threat to the financial security of the investors is the borrower's moral hazard.In P2P lending, both sides signed borrowing funds in the contract after the formation of principal agency relationship, due to the asymmetry of information, cost is too high for investors to monitor the behavior of borrowers, borrowers are difficult to track borrowed funds whereabouts, 
generally do not participate in the borrower's daily business activities. So in order to obtain higher profits, borrowers may have will loan investment projects with high risk, which is likely to cause the overdue loans and bad debts, a large number of overdue and bad debts the platform can not continue to operate, the lender's money is hard to recover back.This behavior by the borrower is not conducive to the lender is the moral hazard of P2P network lending. Moral hazard not only harm the interests of investors, but also to the development of P2P lending platform has caused some impact, but also reduce the market efficiency.

Moral hazard is caused by the asymmetry of information to the lender to make selfish behavior to provide convenience, on the other hand, because of the moral hazard of the borrower to pay low cost. So to prevent moral hazard of $\mathrm{P} 2 \mathrm{P}$ lending industry can by regulatory authorities to make the relevant provisions, including increase the information transparency of platform,Improve the personal credit system in China, establish the credit information sharing platform and services P2P lending which developing better.On the other hand,Implement mortgage loans, increase the borrower's default cost, or establishing credit guarantee mechanism, the borrower's credit review, screening a relatively high level of moral and good credit customers, reduce the possibility of moral hazard.

\section{Conclusion}

In the past two years,P2P network lending have experienced explosive growth. When more and more problems come out, the end of 2015 P2P regulations officially landed prompted the industry by the throes of gradually into the mature period of development.The arrival of the era of financial sharing means that financial activities become more and more transparent, which means financial consumer began to become active, which means the idle resources need to be invigorated, this is undoubtedly to P2P network lending industry entered a mature development track with opportunities.

\section{Reference}

[1]Tu Jing, Tong Zeping. Risk security payments, overdue loans and P2P net loan platform runs [J]. financial theory and practice. 2016 (02)

[2]Liang Chenxi. Based on risk control of small and micro enterprises Internet financial model innovation research -- take the P2P net loan platform as an example [J]. Economist, 2016,01:8485 .

[3]Zhang Rijin. Study on the risk control of P2P network lending in China [D]. Zhejiang University, 2015.

[4]Cao Menglu.P2P network lending risk study [D]. Shandong University, 2015,05 